\title{
The Effect of Problem-Based Learning Strategy to Students' Ability in Writing Argumentative Text at Muhammadiyah University of Bengkulu
}

\author{
ERLIAN DWISNU 1 \\ ${ }^{1}$ Sekolah Tinggi Ilmu Administrasi Bengkulu, Bengkulu, Indonesia \\ erlian.dwisnu@yahoo.com
}

\begin{abstract}
The question posted in this study was "Did the Problem Based Learning Strategy give effect to the students' ability in writing argumentative text in English Study Program of Muhammadiyah University of Bengkulu?". The aim of this study was to examine whether problem-based learning strategies affect students' ability to write argumentative text in English Study Program of Muhammadiyah University of Bengkulu. The methodology of this research was experimental research. With 146 students, the samples for this study consisted of two classes. Class B has 20 students and class C 20 students. The researchers took courses B and $\mathrm{C}$ because they had similar subject-writing skills. The researcher took class $\mathrm{B}$ and $\mathrm{C}$ because they have similar skill in writing I subject. The data were obtained from the pre-test before the treatment in three meetings and post-test after the treatment by using Problem-Based Learning Strategy in experimental class. Students' writing product is assessed by using analytical scoring rubric. The last step was the researcher discussed and concluded the data. The result of this research showed that Problem Based Learning Strategy can improve students' writing skills. Calculated using T-test formula, it was found that t-count is higher than $\mathrm{t}$ table $(2.9>2.0024)$ and The average score of the two classes was increased, the experimental class got increasing as much as 38.7 points, while in control class indicate the increasing as much as 3.8 points. So, it can be concluded that this strategy gave a positive effect to the student's ability in writing argumentative text.
\end{abstract}

Keywords: effect, problem-based learning, writing ability, argumentative text

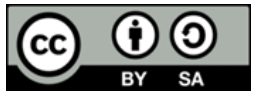

Copyright (C) 2021 The Author(s)

This is an open-access article under the CC BY-SA

license. 


\title{
Pengaruh Penggunaan Problem-Based Learning Strategy terhadap Kemampuan Siswa dalam Menulis Text Argumentatif di Universitas Muhammadiyah Bengkulu
}

\begin{abstract}
Abstrak
Pertanyaan yang diajukan pada kasus ini adalah "apakah ProblemBased Lerning Strategy berpengaruh terhadap kemampuan siswa dalam menulis text argumentative di program studi Bahasa Inggris Universitas Muhammdiyah Bengkulu?" hasil dari penelitian ini adalah untuk mengetahui apakah Problem-Based Lerning Strategy mempengaruhi kemampuan siswa dalam menulis text argumentative pada jurusan Bahasa Inggris Universitas Muhammadiyah Bengkulu. Metode penelitian ini adalah penelitian eksperimen.Jumlah populasi adalah 146 siswa dan sampel terdiri dari dua kelas. Ini adalah Kelas B dengan 20 siswa dan Kelas C dengan 20 siswa. Peneliti mengambil kelas B dan C karena mereka memiliki kemampuan yang sama dalam writing I. data diperoleh dari pre-tes sebelum tiga kali perlakuan menggunakan problembased learning strategy di kelas eksperimen dan post-tes setelah perlakuan. Hasil penelitian di nilai dengan menggunakan rubrik penilaian analitikal. Langkah terakhir peneliti mendiskusikan dan menyimpulkan data. Dalam penelitian ini didapat bahwa strategi problem-based learning dapat meningkatkan keterampilan menulis siswa.. Hal ini bisa di lihat dengan mengguna $\mathrm{Hal}$ ini dapat dikonfirmasi dengan menggunakan rumus T-test yaitu t-count lebih tinggi dari t-tabel $(2.9>2.0244)$ dan nilai rata-rata kedua kelas meningkat, kelas eksperimen memperoleh peningkatan sebesar 38.7 poin, sedangkan control kelas memperoleh peningkatan sebesar 3.8 poin. Jadi, bisa di simpulkan bahwa strategi ini memberikan efek positif terhadap kemampuan siswa dalam menulis teks argumentative.
\end{abstract}

Kata kunci: efek, problem-based learning, kemampuan menulis siswa, teks argumentative.

\section{INTRODUCTION}

Problem-based learning (PBL) is an approach to learning and education in which students solve problems in small groups under the supervision of a tutor (Cheong, 2008). In problem-based learning, students work on a given situation/problem in small groups. The problem is presented for students to apply reasoning, questioning, research and critical thinking to find a solution to the problem. In a nutshell, PBL is an educational learning process strategy that focuses on students finding solutions to problems, students working in groups, facilitators, 
and teachers as supervisors. A problem-based learning strategy widely used in medicine, dental science, forensic examination, and speech therapy, but also used in non-medical courses such as accounting, architecture, economics and languages (Azer Samy, 2008).

PBL incorporates innovative, relevant and meaningful teaching and learning methods that actively engage students and provide intelligible language input and skills. Indeed, there are many opportunities for language development in combination with the acquisition of knowledge in the content domain using this model. Suitable for language teaching, PBL also wants students to be more active in the education and learning process. We can conclude that PBL is used not only for doctors and saints, but also for language skills. Indeed, there are many opportunities for language development in combination with the acquisition of knowledge in the content domain using this model. Suitable for language teaching, PBL also wants students to be more active in the education and learning process. Writing is one of the language skills.

Writing is an act of discovery that allows the writer to develop what he wants to say during the writing process, not before (Hairston, 1982). In the writing process, students should actively develop ideas in the text. When teaching writing using a question-based learning strategy, students can work in groups and share it with other students in the class. These approaches are particularly effective for English learners. This is because the students have many opportunities to interact in small groups (Slavin,nd). While the students work in groups, gather information, discuss problems, reflect and choose the best solution. Stakes, the role of the facilitator is to observe and assist (Mathews-Aydinli, nd) concretely; the facilitator takes notes on the language used, the language problems encountered, and the involvement of each learner born in the 'action. Teachers should see if students have specific grammar, vocabulary and pronunciation problems. In summary, PBL strategies are also related to the writing skills that students work on. Students write texts about problems, hypotheses and solutions to problems.

Problem-based learning strategies help students develop competent intellectual and communication skills, both oral and written. so, teachers can not only observe student activity in the classroom, but also use textbooks to assess students' abilities. Based on the researcher personal experience, when the researcher took writing subject; it was found that most of students felt dificult in developing the ideas in writing. The students thought that writing was difficult, boring and scary subject in English. The students did not have a good capability to 
write in English althought they have learnt how to write. However, the writing activities are designed monotonously by the lecturers. The lecturers simply ask students to arrange words into sentences and sentences to be paragraph or arrange jumbled paragraph into a good arrangement. It's mean that, lecturers of writing have to be creative in teaching writing to avoid monotonous and boring activities. Problem-based learning is a strategy that describes learning as an active process allowing students to build new ideas and concepts based on existing knowledge. so the lecturers can apply the Problem- Based Learning strategy where the students can be active and creative to find a solution to the problem by written. In writing, students can offer a means of exploring their own thinking and it's a way to examine what the students know about a subject.

Based on the above written teaching phenomenon, researchers try to apply to apply The Problem - Based Learning Strategy in Teaching Writing at The Fourth Semester Students in English Study Program of Muhammadiyah University of Bengkulu.

\section{METHOD}

The design of this study is an experimental study. Empirical studies are unique in one very important way. The term design of experiments refers to the conceptual framework in which tests are conducted (Ary, Jacobs, Razavieh \& Ary, 2010). The study was divided into two groups, an experimental group and a control group. Each group was treated with different treatments. Researchers have taught using problem-based learning strategies In the control group, researchers taught without problem-based learning strategies. Prior to treating the experimental group, the researchers pre-tested the two groups. The most beautiful purpose is to see if the two groups are in the same situation. After three treatments in both groups, the researchers performed the following tests on the groups. The question is whether the use of problem-based learning strategies is effective in teaching writing. And he did not use problem-based learning strategies in the control group

The design of this research was as follow:

Table 1. Table of Control Groups and Experimental group

\begin{tabular}{|l|l|l|l|}
\hline Groups & Pre-test & Treatments & Post-test \\
\hline $\begin{array}{l}\text { Experimental } \\
\text { group }\end{array}$ & $\mathrm{Y} 1$ & $\mathrm{X} 1$ & $\mathrm{Y} 2$ \\
\hline Control group & $\mathrm{Y} 1$ & $\mathrm{X} 0$ & $\mathrm{Y} 2$ \\
\hline
\end{tabular}


Where :

Y1 : Pre-test

Y2 : Post-test

X1 : Using Problem-Based Learning strategy

XO : Without using Problem-Based Learning strategy

Population and Sample

The subjects of this study included students in the fourth semester of the English Department at Muhammadiyah University of Bengkulu. All numbers in the selected group show similar characteristics based on the average scores of the two previous test classes selected by the researcher as a sample for this study. The sample for this study consisted of two classes. That is, Class B with 33 students and Class C with 32 students. However, the researchers took only 20 students for the calculations. Therefore, the sample for this survey are 40 students. The researchers took courses $\mathrm{B}$ and $\mathrm{C}$ because of their poor writing skills.

Data Collecting Technique

Data collection is the most important step in conducting a survey. To obtain the data, the researchers followed the steps below:

1. The researcher took pre-data.Data obtained by researchers on the basis of student notes. The researcher took two classes that have low skill in Writing I subject.

2. The researcher gave pre-test to the students. The classes that was taken were $\mathrm{B}$ and $\mathrm{C}$ class because based on the students' score in Writing I, these classes got the lowest score from the other class in Writing subject.

3. The researcher gave treatments and observed when the student did the writing test. So the researcher could see the students' skill in writing subject clearly. And the researcher and co-researcher would not make mistake in giving score.

4. The researcher gave post-test after conducting the treatment three meetings. In order to knew increasing of their writing ability at the two classes.

\section{Research Instrument}

The instruments of data in this research are:

\section{Writing Test}

The written exam used in this study is a discussion of a particular topic or question. In this activity, students are asked to write and discuss assignments 
based on topics or questions given by the researcher, who also bring up different topics at each conference.

2. Handy Cam or Digital Camera

The researcher took the data by using handy cam or digital camera to saw the students' skill in using Problem-Based Learning Stretegy in Writing II subject.

3. Analytic Scoring Rubric

Technique for Analyzing Data

1. The researchers used analytical grade sheets to assign grades to students. When analyzing the data, the researchers used specific steps. The researchers took the writing test in an experiential class and controlled and ranked the students' writing skills based on factors of the writing score (content, composition, vocabulary, language used). ). and mechanics) (Reid, 1993).

2. In analyzing the data, the researchers were assisted by the principal investigator.The researcher and co-researher gave the score for writing test by using analytical scoring rubric, the researcher combined the results of writing test from researcher and co-researcher then the result of writing test by using criteria (table 2) for the assessment to know students ability in writing II subject for experiment through Problem-Based Learning Strategy and control class without Problem-Based Learning Strategy.

Table 3.4 The Criteria For Scoring The Writing Task

\section{Content}

30-27 excellent to very good: knowledgeable - substantive development of thesis - relevant to assigned topic.

26-22 good to average: some knowledge of subject - adequate range limited development of thesis - mostly relevant to the topic but lack detail

21-17 fair to poor: limited knowledge of subject - little substance inadequate development of thesis.

16-13 very poor: doesn't show the knowledge of subject - non substantive - not pertinent - or not enough to evaluate

Organized

20-18 Good to very good: fluently expressed - ideas clearly expressed/supported - concise - well organized - logically organized

17-14 Moderately good: somewhat jerky - None organized but outstanding main ideas - Limited support - Logical arrangement but incomplete

13-10 Moderate to poor: not fluent - confused or separated ideas - lacks logical sequence and development

9-7 very poor: no communication - not organized - or not enough to 


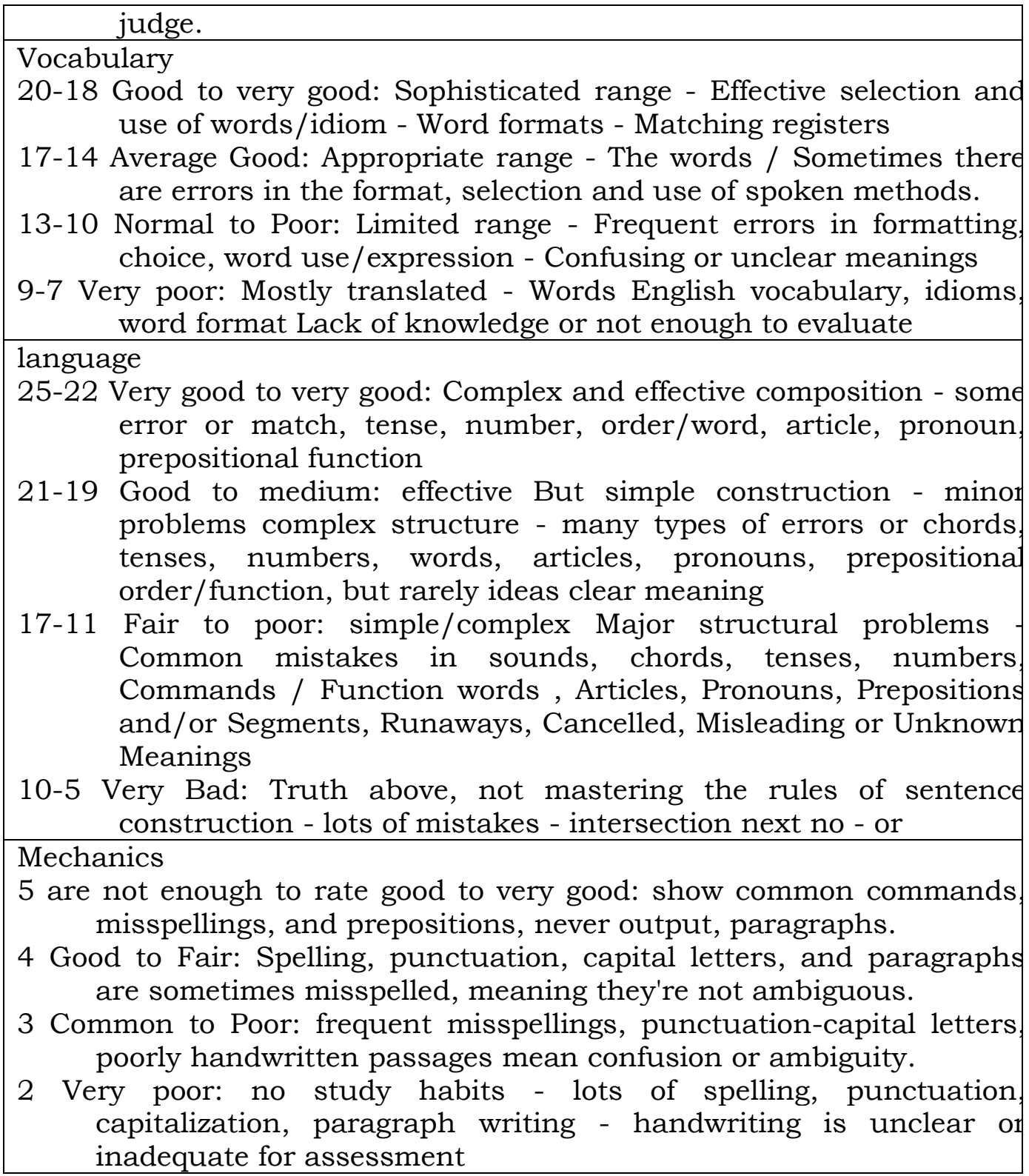

Adopted from Reid (1993)

3. The researcher tabulated the data from the scoring rubric.Then, the Researcher used t-test formula to know the significant of using Problem-Based Learning Strategy from the control and experiment class, the formula is as follow:

$$
t=\frac{\overline{X_{1}}-\overline{X_{2}}}{\sqrt{\frac{\sum X_{1}^{2}-\left(\sum X_{1}\right)^{2} / n_{1}+\sum X_{2}^{2}-\left(\sum X_{2}\right)^{2} / n_{2}}{\text { T-test }^{2}=\text { T count }^{n_{1}}+n_{2}-2}\left(\frac{1}{n_{1}}+\frac{1}{n_{2}}\right)}}
$$

$\overline{\mathrm{X}} 1=$ Mean score for the experimental 


\begin{tabular}{cl} 
Erlian Dwisnu & The Effect of Problem-Based Learning Strategy to Students' Ability ... \\
\hline X 2 & $=$ Mean score for control class \\
$\sum$ X 1 & $=$ Sum of students score by experiment class \\
$\sum$ X 2 & $=$ Sum of students score by control class \\
n 1 & $=$ The number of students in the experimental class \\
n 2 & $=$ The number of the students in the control class
\end{tabular}

\section{FINDINGS AND DISCUSSION}

\section{Findings}

The case was take at Muhammadiyah University in Bengkulu to gather information on the impact of using problem-based learning strategies on students' skill to write argumentative texts. The results showed that the students improved their ability to write argumentative passages using Problem-Based Learning Strategy. It is very important to compare the results before and after the test. We will present it in the next section.

\section{The Pre-test Result}

Both classes (experimental and control classes) received the best essays to test students' writing skills before researchers took experimental classes. In the experimental class, the researchers used problem-based learning strategies as a treatment, while in the control classes, the researchers taught without using problem-based learning strategies. Ideally, the researcher asks the student to write a argumentative text based on the topic proposed by the researcher. The best results of the sample were analysed by the T-test equation and found that $\mathrm{t}$-table was 2.02 (significance level $=0.05$, $\mathrm{df}=\mathrm{n} 1 \mathrm{n} 2-2=2020-2=38$ ). $\mathrm{T}$-count is compared to T-table and it turns out that t-count is smaller than t-table $(8.5$ etlt; 2.02). In conclusion, there was a significant difference in mean pre-treatment test scores (using a question-based learning strategy). The mean score for the experimental class is 8.05 and the mean score for the control class is 60.85 . The highest score in the experimental class was 70 , the lowest score was 37 , the highest score in the control class was 85 , and the lowest score was 1 . This means that the average score of the experimental class is low. Control class.

\section{Treatment}

After classification into two groups, the researchers administered an experimental class and a control class. During the education and learning process, the researchers used the problem-based learning strategy as an experimental 
treatment in the classroom, while the control classes were taught without the problem-based learning strategy about the problem.

\section{In the experimental classroom (using problem-based learning)}

\section{Treatment 1}

The score in treatment I showed that, some groups of students did not describe well about their argument and the students did not make a good solution for the problem. There were several mistakes in sentences and grammar.

\section{Treatment 2}

The students discussed and shared with their group about the topic or problem, then they wrote it in group. In addition, the students' writing in the groups are better than writing by individual.

\section{Treatment 3}

The students discussed and shared with their group about the topic or problem, then they wrote their opinion on a piece of paper per group. The result, the students were enjoy in working with their groups. And they explored their ideas clearly.

\section{In the Controller Class (do not using problem-based learning)}

The researcher only gave them explanation about argumentative text and example of argumentative text.the time 40 minutes that was given in controll class was same with experimental class. The researcher also explained about Problem-Based Learning Strategy, but it did not applied in the control class. It just added the students' knowledge about Problem-Based Learning Strategy.

\section{The Post-Test Result}

After the researcher had done treatments by using Problem-Based Learning Strategy for three times in experimental class, At the last meeting, both classes were tested. With The topic is "Students have difficulty mastering four skills in English". The post test results were analyzed by using t-test formula.

The t-table was found to be 2.0244 (significance level $=0.05$, df $=\mathrm{n} 1 \mathrm{n} 2-2=$ 20 20-2 = 38). Comparing $\mathrm{T}$-count with $\mathrm{T}$-table, we found that $\mathrm{t}$-count was greater than t-table $(2.91>2.0244)$. The bottom line is that $\mathrm{H} 1$ is accepted and $\mathrm{Ho}$ is rejected. In other words, there is a significant difference between the mean posttreatment score of the experimental class (with PBL) and the mean score of the students in the control class (without PBL). In summary, question-based learning strategies help improve students' writing skills. Therefore, it can be said that it has been successfully treated as a problem-solving learning strategy. In the 
experimental class, the highest score was 92 and the lowest score was 80 . In the control class, the highest score was 90 and the lowest score was 8 . Students in the two classes had different writing skills after being able to handle them. It will be classified. Test class students had high scores and argumentative writing skills, while control class students had a small difference from post-test writing skills. Analyse the results before and after the test

Table 1: The Pre-test Result for the Experimental Class

\begin{tabular}{|l|l|l|l|l|l|l|}
\hline $\begin{array}{l}\text { Number } \\
\text { of } \\
\text { Student }\end{array}$ & $\begin{array}{l}\text { Highest } \\
\text { Score }\end{array}$ & Frequency & $\begin{array}{l}\text { Lowest } \\
\text { Score }\end{array}$ & Frequency & Total & Mean \\
\hline 20 & 70 & 1 & 37 & 1 & 961 & 48.05 \\
\hline
\end{tabular}

Table 2: The Pre-test Result for the Control Class

\begin{tabular}{|l|l|l|l|l|l|l|}
\hline $\begin{array}{l}\text { Number } \\
\text { of } \\
\text { Student }\end{array}$ & $\begin{array}{l}\text { Highest } \\
\text { Score }\end{array}$ & Frequency & $\begin{array}{l}\text { Lowest } \\
\text { Score }\end{array}$ & Frequency & Total & Mean \\
\hline 20 & 85 & 1 & 41 & 1 & 1217 & 60.85 \\
\hline
\end{tabular}

From the table above, you can see the pre-test score of students. A student with the highest score in the experimental class is 70 and a student has the lowest score of 37. From the calculation, the average score is 48.05. In the control class, a student scored the highest score of 85 and the lowest score of 41 for a student. The average remark is 60.85 .

Table 4: The Post-Test Result for the Experimental Class

\begin{tabular}{|l|l|l|l|l|l|l|}
\hline $\begin{array}{l}\text { Number } \\
\text { of } \\
\text { Student }\end{array}$ & $\begin{array}{l}\text { Highest } \\
\text { Score }\end{array}$ & Frequency & $\begin{array}{l}\text { Lowest } \\
\text { Score }\end{array}$ & Frequency & Total & Mean \\
\hline 20 & 92 & 5 & 80 & 5 & 1735 & 86.75 \\
\hline
\end{tabular}

Table 5: The Post-Test Result for the Control Class

\begin{tabular}{|l|l|l|l|l|l|l|}
\hline $\begin{array}{l}\text { Number } \\
\text { of }\end{array}$ & $\begin{array}{l}\text { Highest } \\
\text { Score }\end{array}$ & $\begin{array}{l}\text { Frequenc } \\
\mathrm{y}\end{array}$ & $\begin{array}{l}\text { Lowest } \\
\text { Score }\end{array}$ & $\begin{array}{l}\text { Frequenc } \\
\mathrm{y}\end{array}$ & Total & Mean \\
\hline
\end{tabular}




\begin{tabular}{|l|l|l|l|l|l|l|}
\hline Student & & & & & & \\
\hline 20 & 90 & 1 & 48 & 1 & 1293 & 64.65 \\
\hline
\end{tabular}

From the table above, we can see that after passing the test, The highest score in the experimental class was 92 , and 5 students got the lowest score for 80 students. The calculation shows that the average score is 86.75. In the control class, one student got the highest score of 90 and the other student got the lowest score of 8 . The average score was 6.65 . From the explanation above, you can see that the scores of both classes are increasing.

Table 6. The Comparison of Pre-Test and Post-Test

\begin{tabular}{|l|l|l|l|}
\hline \multirow{2}{*}{ Groups } & \multicolumn{2}{|l|}{ Mean Score } & \multirow{2}{*}{ Increasing } \\
\cline { 2 - 3 } & Pre-Test & Post-Test & \\
\hline Experimental class & 48.05 & 86.75 & 38.7 \\
\hline Control Class & 60.85 & 64.65 & 3.8 \\
\hline
\end{tabular}

Based on the table above, compare the best test and average test scores between the experimental and control classes. In the best sense, the experimental class score is lower than the control class score. In the test, the average score of the experimental class using the inquiry-based learning strategy as a treatment was higher than the average score of the control class taught without the inquiry-based learning strategy. The experimental class increased to 38.7 points. Control class increased to 3.8 points. Researchers concluded that the use of problem-based learning strategies had a significant impact on students' ability writing argumentative text at the fourth semester in English department of Muhammadiyah University of Bengkulu.

\section{Discussion}

Based on the interviewer's comments, most classes find it difficult to show their views in writing, especially in argumentative texts. Students do not want to write actively. At least they're tired of composing. To solve this problem, teachers should try to use certain strategies to teach writing. One of them is using a problem-based learning strategy. Problem-based learning (PBL) is an approach to learning and education in which students solve problems in small groups under the supervision of a tutor. (Cheong, 2008) 
When the researchers looked at the five classes for the first time, they found that grades $\mathrm{B}$ and $\mathrm{C}$ had the same writing quality and the lowest writing scores. One class is an experimental class and a control class. The researchers chose which of the two intact classes the experimental class was and the other was the control class. Therefore, the researchers chose grades B as the control class and grades $\mathrm{C}$ as the experimental class.

First, the researchers managed the best groups into two groups. The purpose of this test is to see if the two classes can write the same way. The researcher then modified the student's handwriting using five handwriting configurations. It uses content, structure, vocabulary, language and mechanism (Reid, 1993). The scoring results show that the mean score in the experimental class is lower than the mean score in the control class. Emphasize that the two classes are very different. Based on the researcher's experience in the pre-test process, researchers are always confused in creating discussion texts based on a certain topic due to the vocabulary and knowledge of the topic. This is still limited. Furthermore, there is no evidence of planning or organization and some of the discussion texts are not quite relevant. This shows that the students are even less capable of writing controversial passages. They also say that controversial texts are difficult for them. Next, the researchers conducted an experiment. This shows the difference in procedure between the experimental class and the control class. The experimental class used a question-based learning strategy, and the control class did not use a question-based learning strategy. However, the materials and themes are similar between the two groups. It started in 3 sessions. The topic is to check the message while some students are still teaching. Some students do not get enough sleep at night. Some students are noisy, provocative and distracting from each other.

During the first treatment, students were still confused when trying to write argumentative texts using problem-based learning strategies. The researchers found that some groups of students did not interpret their arguments well and the students could not find good solutions to the problems. Other students discuss other topics unrelated to the topic provided by the researchers. The researchers also found some mistakes in the students' hand writing and grammar. During the second treatment, the researchers found that the students were still confused, but this student's remark was higher than that of the student who received the first treatment. The students focused on specific topics brought up by the researchers and discussed well with their group. 
During the third treatment, the researchers confirmed that the students enjoyed working in groups. As students gain knowledge and information from the group, they are motivated to write their discussions on topics and problems.. Like (Hatfield, Ajaan Rob, 2012) “Students' problem-solving motivation drives students to seek and apply knowledge," he said. And they clearly explored their ideas. They can develop their arguments better than Methods I and II. The students felt greatly helped from the small group work. As a result of this refinement, students appeared to focus on writing argumentativetexts, and using problem-based learning strategies improved their performance. In flipped classrooms, where researchers teach argumentativetexts without using problem-based learning strategies, researchers can keep student handwriting constant, even as student handwriting increases but does not make sense. I noticed yes. Students have limited knowledge of the subject as they work individually and cannot share it with their friends.

From this explanation, it can be concluded that there is a significant difference in the writing results of the students of the experimental class and the control class. Researchers can also report that students in the experimental class felt really happy and excited about writing in PBL because they could write and share in groups. The use of problem-based learning strategies is very instructive. The students were very active in discussing their writing with the group. The students enjoyed working in groups. And they clearly explored their ideas. The students can develope their argument better than when they write individually. In addition, According to Hatfield, Ajaan Rob (2012), Through problem-based learning, students can improve their problem-solving skills, research skills, and social skills. In addition, PBL benefits students in the following ways: Increases motivation to learn. Gain critical thinking, writing and communication skills. Improved information retention. It provides a lifelong learning model.

In the control class; the researcher gave the same topics with experimental class. But the researcher taught them without using Problem-Based Learning Strategy. The researcher only gave them explanation and example of argumentative text. The situation in control class was diferent, some of students felt dificult in developing their ideas. The researcher found that some students were not interested in writing freely with their ideas, and they still had limited argument in their writing. It is because of the students just wrote individually and couldn't share with their friends. In traditional course the students listen pasively to lecturers with a large number of students, while in PBL the students actively work in small groups (Azer Samy, 2008) 
The tests are performed after the researcher has completed the treatment. The test is administered in two classes and evaluated by researchers and collaborators. This test aims to understand the impact of question-based learning strategies on students' writing skills. The test results show an excellent composition of the experimental classes on the basis of several criteria such as content, composition, vocabulary, use of language and mechanics (Reid, 1993). In experimental lessons, students can very clearly promote the idea and purpose of the argumentative text. Students can effectively write and present discussions and solutions to problems and topics. Student vocabulary is the factor influencing students to develop their ideas when writing controversial texts. On the other hand, the grammar model was accurate and made effective use of noun and adjective phrases. Second, the spelling, mechanics, punctuation, and case sensitivity are mostly correct. The gain in the experimental class was larger than the gain in the control class. From the above explanation, it can be said that the healing effect is very high. It showed that the students' writing scores before treatment (pre-test score), during and after treatment (post-test score) increased significantly.

Based on finding above, the researcher concluded that problem-based learning gave positive effect to students' writing ability. After calculating using Ttest formula, we can see that t-count is larger than t-table $(2.91>2.0244)$. This is because problem-based learning can greatly benefit students in writing and enhance their ability in content, composition, vocabulary, language use, and mechanics. Certain problems arose before the researchers started treatment. However, after applying three treatments, researchers were able to see an increase in students' ability to write discussion texts. In the next test, the mean score of the experimental class using the question-based learning strategy as a treatment was higher than the mean score of the control class taught without the question-based learning strategy. This shows that the experimental class increased by 38.7 points and the control class increased by 3.8 points. This means that there is a significant difference between the experimental class and the control class. Therefore, $\mathrm{H} 1$ is accepted and Ho is rejected. Researchers concluded that the use of problem-based learning strategies had a significant impact on students' ability to write argumentative texts in the fourth semester of the English department at the University of Muhamadiyah in Bengkulu. 


\section{CONCLUSION}

Problem-based learning affects students' ability to write texts for discussions in the fourth semester of the Learn English program at Muhammadiyah University in Bengkulu. The results of the previous time show that the mean score of the experimental class is lower than the mean of the control class. Post-test results show that the mean score in the experimental class is higher than the mean score in the control class, but the mean score in both classes' increases. Calculations using the T-test formula show that T-count is greater than T-table. The researchers concluded that the use of problem-based learning strategies had a significant impact on the students' ability to write argumentative texts during the fourth semester of the English department at Muhammadiyah University in Bengkulu.

\section{REFERENCES}

Ary, D., Jacobs, L. C., Razavieh, A., \& Ary, D. (2010). Introduction to research in education (8th ed). Belmont, CA: Wadsworth.

Azer Samy. (2008). Navigating Problem-Based Learning. Australia: Churchill Livingstone.

Cheong, F. (2008). Using a Problem-Based Learning Approach to Teach an Intelligent Systems Course. Journal of Information Technology Education: Research, 7, 047-060. https://doi.org/10.28945/178

Hairston, M. (1982). The Winds of Change: Thomas Kuhn and the Revolution in the Teaching of Writing. College Composition and Communication, 33(1), 76-88. https: / / doi.org/10.2307/357846

Hatfield, Ajaan Rob. (2012). Review of Problem Based Learning (PBL) in the English Language Learning Classroom. 2011.

Mathews-Aydinli, J. (n.d.). Problem-Based Learning and Adult English Language Learners. 8.

Reid, J. M. (1993). Teaching ESL Writing. United States of America. United States of America: Prentice-Hall.

Slavin, R. E. (n.d.). Instruction Based on Cooperative Learning. 33. 


\section{Author's Curriculum Vitae}

\section{Erlian Dwisnu}

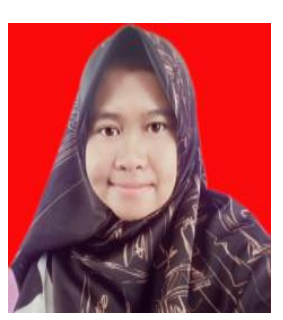

Erlian Dwisnu, the second daughter of Edwaryo and Lisandora, was born in Lebong on December 27th, 1991. She was graduated from Elementary School Number 42 of Lebong Tengah in 2004. She continued her study to Junior High School number 2 of Lebong Tengah in 2007, and graduated from Senior High School number 1 of Lebong Tengah in 2010. She continued her study to Muhammadiyah University of Bengkulu. She took an English Language Study Program and graduated in 2014. Next year, on February 2015, she decided to continue her study at Magister Program of English Education in Bengkulu University and finished her master degree in 2017 . Moreover, she started her teaching career at Madrasah Ibtidaiyah number 1 of Bengkulu city, Lecturer of Bengkulu State Institute of Islam literature (IAIN) and the lecturer of Bengkulu Education Board Administration College (STIA). 